\title{
Meacham syndrome
}

INSERM

\section{Source}

INSERM. (1999). Orphanet: an online rare disease and orphan drug data base. Meacham syndrome. ORPHA:3097

Meacham syndrome is a multiple malformation syndrome characterized by congenital diaphragmatic abnormalities, genital defects and cardiac malformations. 